\title{
Firing rate response of neocortical neurons in the fluctuation-driven regime
}

\author{
Yann Zerlaut*, Gilles Ouanounou, Bartosz Telenczuk, Charlotte Deleuze, Thierry Bal, Alain Destexhe \\ From 24th Annual Computational Neuroscience Meeting: CNS*2015 \\ Prague, Czech Republic. 18-23 July 2015
}

Characterizing the input-output properties of neocortical neurons is of crucial importance to understand the properties emerging at the network level. While deriving those input-output relations for artificial neuronal models has been the object of intense investigations, determining those properties for real neocortical cells remains both experimentally and theoretically challenging [1].

Here, we identify four somatic variables that characterize the dynamical state at the soma in the fluctuation-driven regime and we investigate the firing rate response of pyramidal neocortical neurons in this four dimensional space by means of perforated patch recordings in mice cortex in vitro.

We compare our measurements with different single compartment models (Integrate and Fire, Exponential Integrate and Fire and Hodgkin-Huxley models) and we discuss the limitations imposed by those models in the input-output relationship. We also construct an analytical template for the firing rate response and we show that it is able to capture the behavior of both neuronal models and neocortical neurons.

Because of the difficulty to reproduce the measured characteristics with single compartment models, our results argue in favor of phenomenological models for the cellular computation, where the complex details of the biophysical features are absorbed within a flexible higher-level description.

Moreover, the transfer functions obtained from neurons in slices will enable building mean-field models based on realistic neuronal properties.

Published: 18 December 2015

* Correspondence: zerlaut@unic.cnrs-giffrr

Unité de Neurosciences, Information et Complexité, CNRS, 91198 Gif sur Yvette, France creativecommons.org/licenses/by/4.0), which permits unrestricted use, distribution, and reproduction in any medium, provided the original work is properly cited. The Creative Commons Public Domain Dedication waiver (http://creativecommons.org/publicdomain/ zero/1.0/) applies to the data made available in this article, unless otherwise stated.

\section{Reference}

1. La Camera G, Giugliano M, Senn W, Fusi S: The response of cortical neurons to in vivo-like input current: theory and experiment. Biological Cybernetics 2008, 99(4-5):279-301.

doi:10.1186/1471-2202-16-S1-P59

Cite this article as: Zerlaut et al:: Firing rate response of neocortical neurons in the fluctuation-driven regime. BMC Neuroscience 2015 16(Suppl 1):P59. and take full advantage of:

- Convenient online submission

- Thorough peer review

- No space constraints or color figure charges

- Immediate publication on acceptance

- Inclusion in PubMed, CAS, Scopus and Google Scholar

- Research which is freely available for redistribution 